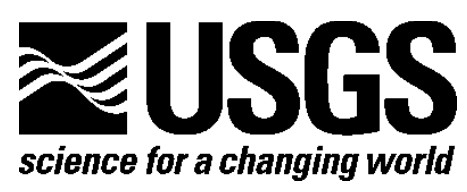

Geology and Geophysics Applied to Groundwater Hydrology at Fort Irwin, California

David C. Buesch, Editor

\title{
Aeromagnetic Data, Processing, and Maps of Fort Irwin and Vicinity, California
}

By V.E. Langenheim and R.C. Jachens

Open-File Report 2013-1024-I

U.S. Department of the Interior

U.S. Geological Survey 


\section{U.S. Department of the Interior \\ SALLY JEWELL, Secretary}

\section{U.S. Geological Survey \\ Suzette M. Kimball, Acting Director}

U.S. Geological Survey, Reston, Virginia: 2014

For more information on the USGS—-the Federal source for science about the Earth,

its natural and living resources, natural hazards, and the environment-visit

http://www.usgs.gov or call 1-888-ASK-USGS (1-888-275-8747)

For an overview of USGS information products, including maps, imagery, and publications, visit http://www.usgs.gov/pubprod

To order this and other USGS information products, visit http://store.usgs.gov

Any use of trade, firm, or product names is for descriptive purposes only and does not imply endorsement by the U.S. Government.

Although this information product, for the most part, is in the public domain, it also may contain copyrighted materials as noted in the text. Permission to reproduce copyrighted items must be secured from the copyright owner.

Suggested citation: Langenheim, V.E., and Jachens, R.C., 2014, Aeromagnetic data, processing, and maps of Fort Irwin and vicinity, California, chap. I of Buesch, D.C., ed., Geology and geophysics applied to groundwater hydrology at Fort Irwin, California: U.S. Geological Survey Open-File Report 2013-1024, 18 p., http://dx.doi.org/10.3133/ofr20131024l. 


\section{Contents}

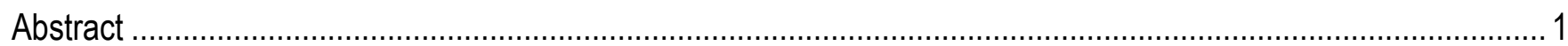

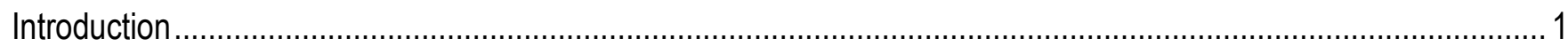

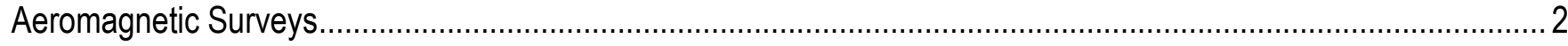

Aeromagnetic Map Processing and Anomaly Enhancement ........................................................................ 2

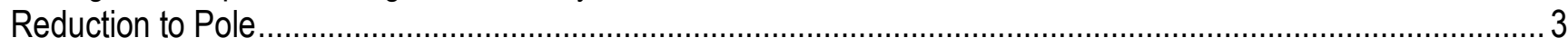

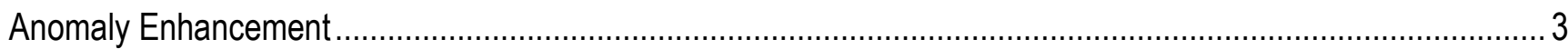

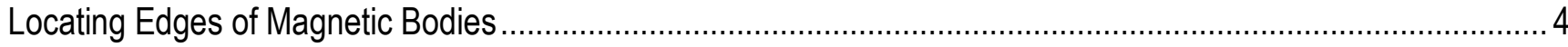

Magnetic Susceptibility Measurements and Anomaly Sources..................................................................... 4

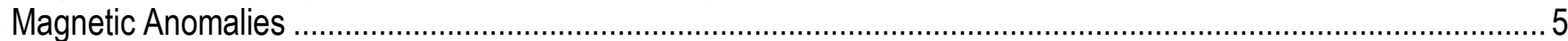

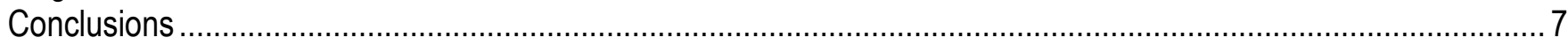

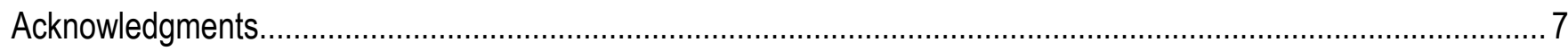

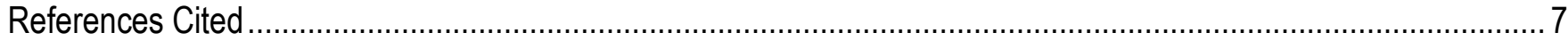

\section{Figures}

1. Simplified geologic map of Fort Irwin over shaded-relief topography .................................................... 10

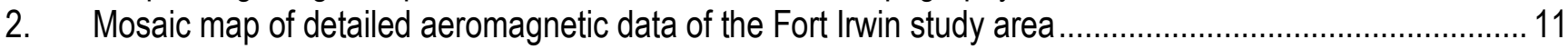

3. Merged aeromagnetic map of the Fort Irwin study area .................................................................. 12

4. Filtered aeromagnetic map of the Fort Irwin study area that enhances anomalies produced by shallow or exposed magnetic sources ............................................................................................... 13

5. Filtered aeromagnetic map of the Fort Irwin study area that enhances anomalies produced by shallow or exposed magnetic sources and shows magnetization boundaries ....................................................... 14

6. Magnetization boundaries superposed on simplified geologic map of the Fort Irwin study area................. 15

7. Bar chart of magnetic-susceptibility measurements from the Fort Irwin study area ...................................16

8. Aeromagnetic and derivative maps of Leach Basin high-resolution helicopter survey ................................ 17

\section{Tables}

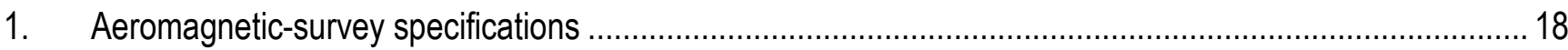

\section{Supplemental Data}

1. Aeromagnetic survey data [Available online only at $h$ ttp://pubs.usgs.gov/of/2013/1024/i/.] 


\title{
Aeromagnetic Data, Processing, and Maps of Fort Irwin and Vicinity, California
}

\author{
By V.E. Langenheim and R.C. Jachens
}

\begin{abstract}
Aeromagnetic data help provide the underpinnings of a hydrogeologic framework for Fort Irwin by locating inferred structural features or grain that influence groundwater flow. Magnetization boundaries defined by horizontal-gradient analyses coincide locally with Cenozoic faults and can be used to extend these faults beneath cover. These boundaries also highlight the structural grain within the crystalline rocks and may serve as a proxy for fracturing, an important source of permeability within the generally impermeable basement rocks, thus mapping potential groundwater pathways through and along the mountain ranges in the study area.
\end{abstract}

\section{Introduction}

Fort Irwin is a major training base for the U.S. Army within the dry Mojave Desert (fig. 1). Water is crucial to maintain successful operations on the base and for any potential expansion or alternative uses of the property. Modern aeromagnetic surveys have been collected over much of the base during the past few decades to aid in understanding the regional geology, to evaluate the risks of natural hazards, and to assess groundwater and mineral resources. These surveys, which were conducted from low-flying aircraft, measured local irregularities (anomalies) in the geomagnetic field that are caused by the presence of magnetic minerals, mostly magnetite, in the underlying rocks. Magnetic anomalies commonly are relatable to rock type, and so these surveys provide a means to remotely map some aspects of the geology, particularly faults that are concealed beneath geologically young deposits and may compartmentalize groundwater flow, as well as magnetic units within the bedrock. As part of this study, a detailed magnetic survey flown by helicopter was conducted over the Leach Basin area simultaneously with the collection of airborne electromagnetic data (fig. 1; P. Bedrosian, written commun., 2014).

The study area (fig. 1) lies within the northeastern part of the Mojave strike-slip province. Basement rocks range in age from Precambrian $(1.4 \mathrm{Ga})$ through Late Cretaceous. Deformational events affecting the basement rocks occurred during the Middle Jurassic and about $105 \mathrm{Ma}$, leaving a pervasive mylonitic fabric in these rocks over much of Ft. Irwin (Schermer and others, 1996). After these rocks were intruded by Late Cretaceous ( $\sim 80 \mathrm{Ma}$ ) granitic plutons (Miller and Sutter, 1982), they were uplifted, eroded, and subsequently overlain by Miocene and younger volcanic and sedimentary rocks. These rocks have been offset by Cenozoic sinistral, east-west-striking and dextral, northwest-striking faults (Schermer and others, 1996; Miller and Yount, 2002). This diverse geologic history has led to lateral contrasts in magnetic properties among these rock types that create measurable magnetic anomalies. Here we present a compilation of aeromagnetic data for the study area, with two derivative 
maps. As detailed below, the first derivative map shows anomalies that arise from exposed or shallowly buried magnetic sources and the second derivative map includes the results of an automatic routine for defining the near-surface edges of magnetic bodies that reflect lithologic and structural features.

\section{Aeromagnetic Surveys}

Six detailed surveys cover most of the study area (fig. 2; table 1). The surveys, which have flightline spacings of $1.6 \mathrm{~km}$ ( 1 mile) or less, were collected during the past 3 decades as integral parts of U.S. Geological Survey investigations of (1) mineral resources in proposed wilderness areas, (2) active faulting, (3) groundwater resources, and (4) regional geology. As part of a hydrogeologicframework study of Fort Irwin (fig. 1), helicopter aeromagnetic data were collected simultaneously with electromagnetic measurements in the northern part of the base, where access is extremely limited because of unexploded ordinance.

Data from the detailed surveys were corrected for diurnal and other short-period magnetic fluctuations resulting from atmospheric and ionospheric sources, and for the Earth's main magnetic field (International Geomagnetic Reference Field [IGRF]; Langel, 1992) estimated for the time period during which the data were collected. The resulting data (fig. 2) were interpolated to a rectangular grid with nodes spaced $250 \mathrm{~m}(820 \mathrm{ft})$ apart, according to an algorithm based on minimum curvature (Briggs, 1974).

The detailed surveys were embedded in less detailed regional data that were compiled as part of the aeromagnetic anomaly map of California (Roberts and Jachens, 1999). The regional data were collected as part of the National Uranium Resource Evaluation (NURE) along flightlines spaced $4.8 \mathrm{~km}$ (3 miles) apart and about $150 \mathrm{~m}(400 \mathrm{ft})$ above terrain. Some minor manipulation and processing of the aeromagnetic data were required to merge the individual surveys into a relatively seamless map of the study area (fig. 3). Differences in topographic relief and ruggedness of topography caused safety concerns that resulted in some surveys being flown, on average, slightly higher or lower than adjacent surveys. These differences were compensated by numerically adjusting the flight height of some surveys to a slightly different effective observation surface, a procedure known as upward continuation (Grant and West, 1965). The NURE and Leach Basin surveys were upward continued to $300 \mathrm{~m}$ to match the terrain clearance of the other surveys. In addition, although the data were theoretically reduced to the same magnetic datum by corrections for diurnal variations and the IGRF, in practical terms some uncertainty exists in the resulting magnetic datum. Therefore, the magnetic datum levels of adjacent surveys were compared in areas of overlap, and the individual surveys were adjusted by adding a constant to all magnetic values within individual surveys. Finally, the individual adjusted surveys were merged into a single dataset by smooth interpolation across a $0.5-\mathrm{km}$-wide buffer zone between surveys, resulting in the unified map shown in figure 3. Comparison of the areas covered by NURE data in figures 2 and 3 highlight the poor resolution of the NURE surveys relative to the more modern, detailed aeromagnetic surveys. The areas covered by NURE data indicate broader (long wavelength) anomalies because of the wide flightline spacing, for example, in the areas south of the Avawatz Mountains, in the Goldstone and Nelson Lake areas, and north of the Garlock Fault and east of Wingate Wash (fig. 3).

\section{Aeromagnetic Map Processing and Anomaly Enhancement}

Although magnetic grain is readily apparent in figures 2 and 3, some simple numerical filtering and manipulation can enhance these anomalies and present them in a form more usable by investigators 
who are not experts in potential-field geophysics. We have applied three straightforward procedures to the data in figure 2 to produce the maps in figures 4 and 5 .

\section{Reduction to Pole}

Magnetic anomalies produced by rocks containing magnetic minerals as a result of induction by the Earth's main magnetic field are generally asymmetric, even when the bodies are symmetrical. Remanent magnetization may be important for some of the Cenozoic volcanic rocks (MacConnell and others, 1994; Ross, 1995; Schermer and others, 1996) but is not anticipated to affect magnetic anomalies arising from the pre-Cenozoic crystalline basement rocks. The asymmetry is caused by the nonvertical main magnetic field and thus is a function of magnetic latitude. In the study area, for example, magnetic anomalies over symmetrical, vertical tabular magnetic bodies display magnetic lows on their north sides with the deepest lows just north of the north edges of the bodies and magnetic highs on their south sides, with the strongest highs just north of the south edges of the bodies.

A numerical procedure called reduction to the pole (Baranov and Naudy, 1964) transforms observed anomalies into those that would have been measured at the magnetic pole where the main field is vertical. This transformation has the effect of centering the magnetic highs directly over the magnetic bodies, with flanking lows on all sides of the highs. In the study area, the inclination and declination (within $1^{\circ}$ ) of the Earth's magnetic field are $61^{\circ}$ and $13^{\circ}$, respectively.

\section{Anomaly Enhancement}

Aeromagnetic maps generally comprise a set of superposed anomalies of many different spatial wavelengths. The amplitude of magnetic anomalies attenuates with increasing distance from the magnetic source and short-wavelength anomalies attenuate more severely with increasing distance relative to longer-wavelength anomalies. In general, the shortest-wavelength anomalies are caused by magnetic bodies at or close to the surface, whereas longer-wavelength anomalies typically reflect deeper magnetic source bodies. Thus, the shortest-wavelength anomalies in figure 2 are most likely produced by rocks that crop out or are only shallowly buried - those rocks that would most likely crop out or would reflect outcropping structures, and would be depicted on a traditional geologic map. These anomalies are of the most direct interest in geologic mapping.

The more severe attenuation with distance of short-wavelength magnetic anomalies (relative to longer-wavelength anomalies) provides the basis for a simple filter to enhance the anomalies from nearsurface sources. If $\mathrm{M}_{\text {pole }}$ is the magnetic-anomaly field shown in figure 2 reduced to the pole, then a magnetic anomaly field with short-wavelength anomalies enhanced with respect to longer-wavelength anomalies $\left[\mathrm{M}_{\text {pole }}\right]_{\text {residual }}$ is given by

$$
\left[\mathrm{M}_{\text {pole }}\right]_{\text {residual }}=\mathrm{M}_{\text {pole }}-\left[\mathrm{M}_{\text {pole }}\right]_{\text {up } 100 \mathrm{~m}}
$$

where $\left[\mathrm{M}_{\text {pole }}\right]_{\text {up } 100 \mathrm{~m}}$ is the magnetic anomaly field in Figure 2, reduced to the pole and upward continued to a surface $100 \mathrm{~m}$ above the original measurement surface, that produced the most continuous, short-wavelength anomalies. The procedure is essentially a discrete vertical derivative, which shows magnetic anomalies arising from approximately the uppermost $1 \mathrm{~km}$ of the crust. This residual field is the magnetic anomaly field shown in figures 4 and 5. 


\section{Locating Edges of Magnetic Bodies}

Cordell and Grauch (1985) devised a scheme for locating the near-surface sharp edges of magnetic bodies on the basis of anomalies they produce, and presented a mathematical transformation called the pseudogravity tranform (Baranov, 1957). Blakely and Simpson (1986) automated this scheme for application to digital representations of magnetic anomaly fields, and the result is a map distribution of closely spaced points that define the edges of magnetic bodies.

The small, black circles shown in figures 5 and 6 represent the inferred surface contacts of outcropping magnetic bodies or the sharp, near-surface edges of shallowly buried magnetic bodies that produce the short-wavelength magnetic anomalies in figures 2 and 4 . These points were automatically generated by applying the method of Blakely and Simpson (1986) to $\left[\mathrm{M}_{\text {pole }}\right]_{\text {residual }}$. This method assumes that magnetic bodies have vertical sides; for nonvertical sides, calculated points will shift in the direction of dip. For sides with moderate to steep $\left(45^{\circ}\right.$ to vertical) dip, however, the horizontal displacement of a gradient maximum from the top edge of an offset horizontal layer is always less than or equal to the depth to the top of the source (Grauch and Cordell, 1987). Because of the altitude at which the data were collected, the resulting aeromagnetic anomaly may be wider than the magnetic source, even if the magnetic source is exposed at the surface.

The various filters (reduction to the pole, upward continuation, anomaly enhancement, and pseudogravity transform) used to produce the magnetic anomaly map (fig. 4) are all linear filters, and so the results are independent of the order in which they are applied (Blakely, 1995).

\section{Magnetic Susceptibility Measurements and Anomaly Sources}

Magnetic data reflect the surface and subsurface distribution of magnetization. The magnetization (in electromagnetic units per cubic centimeter $\left[\mathrm{emu} / \mathrm{cm}^{3}\right]$ ) of a rock is the sum of the remanent and induced components. The remanent component is not easily measured in the field and is discussed later; the induced component depends on the magnetic susceptibility (in cgs units), which is easily measured in the field. Magnetic susceptibility information on exposed rock types is critical to determining the sources of magnetic anomalies. Magnetic susceptibilities of the various rock types compiled and collected for this study are summarized in figure 7.

The most magnetic rock types in the study area (fig. 1), in general, are pre-Tertiary plutonic rocks. Mafic compositions generally are more magnetic, with a mean magnetic susceptibility of $0.73 \times 10^{-3} \mathrm{cgs}$ unit. One sample of mafic plutonic rocks has the highest recorded magnetic susceptibility, $2.73 \times 10^{-3} \mathrm{cgs}$ unit. Pre-Tertiary felsic to intermediate-composition plutonic rocks have a lower mean magnetic susceptibility $\left(0.27 \times 10^{-3} \mathrm{cgs}\right.$ unit $)$, with the maximum of $2.5 \times 10^{-3} \mathrm{cgs}$ unit. The magnetic susceptibilities of the plutonic rocks are very heterogeneous, as indicated by standard deviations that exceed the average magnetic susceptibilities.

Measured magnetic susceptibilities indicate that Tertiary volcanic rocks are also capable of producing prominent magnetic anomalies. The mean magnetic susceptibility of these rocks is $0.22 \times 10^{-3}$ cgs unit, with a maximum of $0.88 \times 10^{-3}$ cgs unit (basalt). Tuffs and altered volcanic rocks generally have lower magnetic susceptibilities $\left(<0.1 \times 10^{-3} \mathrm{cgs}\right.$ unit), whereas lava-flow rocks are generally more magnetic $\left(>0.2 \times 10^{-3}\right.$ cgs unit).

Other rock types sampled in the study area include slate, quartzite, and Jurassic metavolcanic rocks. The magnetic properties of the metamorphic sedimentary and volcanic rocks (fig. 7) are very weak, generally less than $0.1 \times 10^{-3} \mathrm{cgs}$ unit. These rocks produce low-amplitude magnetic anomalies mostly undetectable by airborne surveys. 
Magnetic susceptibility contributes to one component of the total magnetization of a rock. The other component, remanent magnetization, is a function of the direction and strength of the Earth's magnetic field when the rock acquired its magnetization. Remanent magnetization can be an important component of the magnetization of Tertiary volcanic rocks but is unlikely to contribute to the magnetization of other magnetic rock types in the study area because of the older age and coarser grain size of the pre-Cenozoic plutonic rocks. Remanent magnetization could be significant for Mesozoic plutonic rocks, as shown for rocks in Arizona (Gettings, 2002); in the study area, however, no direct information is available to assess the importance of remanent magnetization for these rock types.

Tertiary volcanic rocks in this region typically include lava flows that individually may have a uniform direction of magnetization. Basalt, andesite, and dacite flows in the Fort Irwin area indicate normal (30 sites) and reversed (5 sites) polarities, with northeast and north-northwest declinations (Schermer and others, 1996). The strength of the remanent magnetization ranges from $10^{-4}$ to $10^{-2}$ $\mathrm{emu} / \mathrm{cm}^{3}$, consistent with other studies. MacConnell and others (1994) reported magnetizations of $1 \times 10^{-3}$ to $2 \times 10^{-3} \mathrm{emu} / \mathrm{cm}^{3}$ for basalts and $0.4 \times 10^{-3}$ to $1 \times 10^{-3} \mathrm{emu} / \mathrm{cm}^{3}$ for rhyolite. Ross (1995) reported magnetizations of $3 \times 10^{-3}$ to $8 \times 10^{-3} \mathrm{emu} / \mathrm{cm}^{3}$ for a basalt and an andesite flow, and $10^{-6}$ to $10^{-4} \mathrm{emu} / \mathrm{cm}^{3}$ for samples of tuff, siltstone, and breccia from the Formations of Poe and Troy Peak and the "Barstow" Formation in the Cady Mountains. In general, volcanic flows are more likely to produce magnetic anomalies than are tuffs and volcaniclastic rocks.

\section{Magnetic Anomalies}

Many of the prominent magnetic anomalies in figures 2 and 3 arise from magnetic variations within the pre-Cenozoic basement, such as the magnetic highs that extend northwestward from the Manix Fault toward Coyote and Superior Lakes, the highs over the Avawatz and Granite Mountains, and the highs east of Bicycle Lake. All these anomalies coincide with outcrops of Mesozoic plutonic rocks. Regionally extensive magnetic lows, such as over Barstow, coincide with Jurassic metavolcanic rocks and some felsic granites.

Although Tertiary volcanic rocks are magnetic, comparison of the magnetic field with outcrops of Tertiary volcanic rocks suggests that these rocks may be generally too thin or too highly variable in magnetic properties to produce regionally coherent magnetic anomalies. Tertiary volcanic rocks, however, are responsible for the patterns of short-wavelength magnetic anomalies, such as those south of Nelson Lake, east of Goldstone Lake, and southwest of Superior Lake. A prominent magnetic low along the Blackwater Fault is likely caused by reversely magnetized Tertiary basalt (fig. 3), two flows that are dated nearby at 3.74 and 3.77 Ma (Oskin and Iriondo, 2004), which lie within a reversedmagnetic chron. We also attribute the magnetic lows east of Goldstone Lake to reversely magnetized Tertiary volcanic rocks.

The wavelengths of magnetic anomalies can be used to support interpretations of basin depth derived from gravity data. For example, magnetic basement closer to the surface will produce shorterwavelength anomalies than basement that is more deeply buried. South of the Coyote Lake Fault is a north-south-trending area of longer-wavelength anomalies that coincides with a north-south-trending basin identified in the gravity inversion (see Jachens and Langenheim, this volume, chap. H). Attenuation of anomalies along the Garlock Fault also coincides with local basins as revealed by the gravity inversion.

The magnetic maps reveal patterns of anomalies that can be related to Cenozoic faults in the Mojave Desert region. Magnetization boundaries can reflect the edges of magnetic rocks that are truncated and offset by faults. The detailed helicopter survey of the Leach Basin (fig. 8) illustrates 
nicely how magnetization boundaries map fault strands. The Garlock Fault is well expressed in the magnetic field, with magnetization boundaries that coincide with strands of the fault along much of its length (magnetic gradients 1a-1e, fig. 8C). Magnetic gradient 1a (fig. 8C), less than $1 \mathrm{~km}$ south of the mapped fault through Leach Lake proper, reflects a strand that marks the north edge of a magnetic block (also identified in older, lower-resolution data by Jachens and Calzia, 1998), yet the eastward continuation of this gradient does not offset a prominent north-south-striking gradient (a, fig. 8C). This suggests that displacement may step to the north (or to the left from an on-the-ground eastward perspective) onto the strand coincident with magnetic gradient $1 \mathrm{~b}$. The region between magnetic gradients $1 \mathrm{a}$ and $1 \mathrm{~b}$ also coincides approximately with a small basin that is defined by a single gravity profile (see Jachens and Langenheim, this volume, chap. H). Such a basin would be expected in a leftstep within a left-lateral fault (or releasing bend) such as the Garlock Fault.

The aeromagnetic data can be used to extend mapped traces of the Garlock Fault beneath young surficial deposits, such as the western parts of magnetic gradients $1 \mathrm{~d}$ and 1e in figure 8C. Magnetization boundaries parallel and subparallel to the fault may also reflect additional strands of the Garlock Fault. Where covered by high-resolution data (figs. 8A, 8B), the southern section of the Death Valley Fault Zone is also expressed in the magnetic field (gradients $2 \mathrm{a}, 2 \mathrm{~b}$, fig. $8 \mathrm{C}$ ).

Other faults that locally coincide with magnetization boundaries include the Manix, Coyote Lake, Bicycle Lake, Tiefort Mountains, Fort Irwin, and Owl Lake Faults (fig. 6). A closer look at the Owl Lake and Granite Mountains Faults indicate magnetic gradients (3a, 4, fig. 8C) that are systematically as much as $1 \mathrm{~km}$ offset from the mapped traces. These gradients may reflect older, concealed strands of these faults and for the Granite Mountains Fault, may allow projection of a concealed fault northwestward to the Garlock Fault Zone. Alternatively, the gradients may reflect nonvertical fault attitudes.

Magnetic anomalies can also provide estimates of offset along the fault. For example, offset magnetic anomalies along the Mount General, Harper Lake, and Calico Faults suggest right-lateral offsets of 3.1, 5.0, and $5.8 \mathrm{~km}$, respectively (white arrows, fig. 3; Jachens and others, 2002). For the Owl Lake Fault, on the basis of previous magnetic data, Guest and others (2003) interpreted about 7.5 $\mathrm{km}$ of left-lateral offset. The absence of any offset attributed to the Coyote Lake Fault (Jachens and others, 2002) suggests that this fault has a very low slip rate and (or) has only been recently active, that it is characterized by vertical rather than horizontal slip, or that it formed along a preexisting basement structure. Strands of the Coyote Lake Fault coincide locally with magnetization gradients (fig. 5), and both gravity data (see Jachens and Langenheim, this volume, chap. H) and magnetic data suggest that the fault extends to the east toward Cronese Lakes. This may indicate that the Coyote Lake Fault has more vertical than horizontal displacement. Near the east end of the fault, the magnetic data show a prominent magnetic high (A, figs. $3,5,6$ ) that extends across the projected fault, likely precluding much vertical or horizontal offset along the fault at this point. The extension of the Coyote Lake Fault may continue to the south of the magnetic high just north of exposed basement.

The prominent magnetic high also limits where the Bicycle Lake Fault can project eastward. The fault bifurcates into two strands, with the southern mapped fault trace changing to a more southerly strike at its east end as that fault trace projects toward the magnetic high. Depth to basement indicates relatively shallow basement in this area, consistent with a slight restraining bend in the fault. The fault must pass along either side of the magnetic high if it has more than $1 \mathrm{~km}$ or so of horizontal offset (the resolution of these data).

Not all magnetization boundaries can be related to faults. Some magnetization boundaries coincide with topographic features that are comprised of magnetic terrain, such as the highs over Tiefort Mountain (TM, fig. 6). Other linear magnetization boundaries reflect lithologic contrasts that are not 
caused by Cenozoic faulting, such as the east-west-trending linear magnetization boundary that is caused by the juxtaposition of magnetic Mesozoic plutonic rocks against nonmagnetic Paleozoic eugeosynclinal sedimentary rocks $(\mathrm{B}$, figs. 5,6$)$. Although this magnetization boundary is aligned with the Coyote Lake fault, no Quaternary fault has yet been mapped there.

\section{Conclusions}

Aeromagnetic data provide constraints on structural features that may influence groundwater flow. Magnetization boundaries defined by horizontal-gradient analyses coincide locally with Cenozoic faults and can be used to extend these faults beneath cover or to map older strands concealed beneath young surficial deposits. These boundaries also highlight the structural grain within the crystalline rocks and may serve as a proxy for zones of fractured rock, an important source of permeability within the generally impermeable basement rocks, thus mapping potential groundwater pathways through and along the mountain ranges in the study area (fig. 1). The structures mapped by the aeromagnetic data, however, need other information to ascertain their hydrologic significance.

\section{Acknowledgments}

We gratefully acknowledge financial support from Fort Irwin. We thank Janet Watt and Kevin Denton for their reviews that improved the manuscript and maps. Andy Morita, Jim Howle, and Bob Carruth (all of U.S. Geological Survey) collected additional rock samples for magnetic-susceptibility measurements.

\section{References Cited}

Amoroso, L., and Miller, D.M., 2006, Surficial geologic map and geodatabase of the Cuddeback Lake 30 x 60 minute quadrangle, San Bernardino and Kern counties, California: U.S. Geological Survey Open-File Report 2006-1276, 30 p., scale 1:100,000.

Baranov, V.I., 1957, A new method for interpretation of aeromagnetic maps-pseudo-gravimetric anomalies: Geophysics, v. 22, p. 359-383.

Baranov, V.I., and Naudy, H., 1964, Numerical calculation of the formula of reduction to the magnetic pole: Geophysics, v. 29, p. 67-79.

Blakely, R.J., 1995, Potential theory in gravity and magnetic applications: Cambridge, U.K., Cambridge University Press, $441 \mathrm{p}$.

Blakely, R.J., and Simpson, R.W., 1986, Approximating edges of source bodies from magnetic or gravity anomalies: Geophysics, v. 51, p. 1494-1498.

Briggs, I.C., 1974, Machine contouring using minimum curvature: Geophysics, v. 39, p. 39-48.

Cordell, L., and Grauch, V.J.S., 1985, Mapping basement magnetization zones from aeromagnetic data in the San Juan Basin, New Mexico, in Hinze, W.J., ed., The utility of regional gravity and magnetic anomaly maps: Tulsa, Okla., Society of Exploration Geophysicists, p. 181-192.

Gettings, M.E., 2002, An interpretation of the 1996 aeromagnetic data for the Santa Cruz basin, Tumacori, Santa Rita, and Patagonia Mountains, south-central Arizona: U.S. Geological Survey Open-File Report 02-99, 44 p., accessed July 11, 2012, at http:/geopubs.wr.usgs.gov/open-file/of0299.

Grant, F.S., and West, G.F., 1965, Interpretation theory in applied geophysics: New York, McGrawHill, 583 p. 
Grauch, V.J.S., and Cordell, L., 1987, Limitations of determining density or magnetic boundaries from the horizontal gradient of gravity or pseudogravity data: Geophysics, v. 52, no. 1, p. 118-121.

Guest, B., Pavlis, T.L., Golding, H. and Serpa, L., 2003, Chasing the Garlock: a study of tectonic response to vertical axis rotation: Geology, v. 31, p. 553-556.

Jachens, R.C., and Calzia, J.P., 1998, A geophysical analysis of the Garlock fault, in Calzia, J.P., and Reynolds, R.E., eds., Finding faults in the Mojave: San Bernardino County Museum Association Quarterly, v. 45, p. 36-41.

Jachens, R.C., and Langenheim, V.E., 2014, Gravity survey and interpretation of Fort Irwin and vicinity, Mojave Desert, California, chap. H of Buesch, D.C., ed., Geology and geophysics applied to groundwater hydrology at Fort Irwin, California: U.S. Geological Survey Open-File Report 20131024 (this volume).

Jachens, R.C., Langenheim, V.E., and Matti, J.C., 2002, Relationship of the 1999 Hector Mine and 1992 Landers Fault ruptures to offsets on Neogene faults and distribution of late Cenozoic basins in the eastern California shear zone: Bulletin of the Seismological Society of America, v. 92, no. 4, p. 15921605.

Jennings, C.W., and Bryant, W.A., compilers, 2010, Fault activity map of California: California Geological Survey Geologic Data Map 6, scale 1:750,000.

Jennings, CW, Burnett, J.L., and Troxel, B.W., compilers, 1962, Trona sheet of geologic map of California: California Division of Mines and Geology, scale 1:250,000.

Jennings, C.W., Strand, R.G., and Rogers, T.H., compilers, 1977, Geologic map of California: California Division of Mines and Geology, scale 1:750,000.

Langel, R.A., 1992, International geomagnetic reference field; the sixth generation: Journal of Geomagnetism and Geoelectricity, v. 44, p. 679-707.

MacConnell, D.F., McCabe, C., Dokka, R.K., and Chu, M., 1994, Paleomagnetic and structural evidence for localized tectonic rotation associated with fault drag in the northeastern Mojave Desert; implications for late Cenozoic tectonic evolution of the Eastern California shear zone: Earth and Planetary Science Letters, v. 126, p. 207-216.

Miller, D.M., Menges, C.M., and Lidke, D.J., 2014, Generalized surficial geologic map of the Fort Irwin area, San Bernardino County, California, chap. B of Buesch, D.C., ed., Geology and geophysics applied to groundwater hydrology at Fort Irwin, California: U.S. Geological Survey Open-File Report 2013-1024 (this volume).

Miller, D.M., and Yount, J.C., 2002, Late Cenozoic tectonic evolution of the north-central Mojave Desert inferred from fault history and physiographic evolution of the Fort Irwin area, California, in Glazner, A.F., Walker, J.D., and Bartley, J.M., eds., Geologic evolution of the Mojave Desert and southwestern Basin and Range: Geological Society of America Memoir 195, p. 173-197.

Miller, E.L., and Sutter, J.F., 1982, Structural geology and ${ }^{40} \mathrm{Ar}-{ }^{39} \mathrm{Ar}$ geochronology of the GoldstoneLane Mountain area, Mojave Desert, California: Geological Society of America Bulletin, v. 93, p. 1191-1207.

Oskin, M., and Iriondo, A., 2004, Large-magnitude transient strain accumulation on the Blackwater fault, Eastern California Shear Zone: Geology, v. 32, p. 313-316.

Roberts, C.W., and Jachens, R.C., 1999, Preliminary aeromagnetic anomaly map of California: U.S. Geological Survey Open-File Report 99-440, 14 p., accessed August 31, 2011, at http://geopubs.wr.usgs.gov/open-file/of99-440/.

Ross, T.M., 1995, North-south-directed extension, timing of extension, and vertical-axis rotation of the southwest Cady Mountains, Mojave Desert, California: Geological Society of America Bulletin, v. 107, p. 793-811. 
Schermer, E.R., Luyendyk, B.P., and Cisowski, S., 1996, Late Cenozoic structure and tectonics of the northern Mojave Desert: Tectonics, v. 15, p. 905-832.

U.S. Geological Survey, 1985, Aeromagnetic map of the Ord Mountains, southern California: Open-File Report 87-005, 9 sheets, scale 1:62,500.

U.S. Geological Survey and National Geophysical Data Center, 2002, Aeromagnetic datasets for the conterminous United States and Hawaii: U.S. Geological Survey Open-File Report 02-361, accessed August 31, 2011, at http://pubs.usgs.gov/of/2002/ofr-02-361.

Walker, J.D., Martin, M.W., and Glazner, A.F., 2002, Late Paleozoic to Mesozoic development of the Mojave Desert and environs, California, in Glazner, A.F., Walker, J.D., and Bartley, J.M., eds., Geologic evolution of the Mojave Desert and southwestern Basin and Range: Geological Society of America Memoir 195, p. 1-18. 


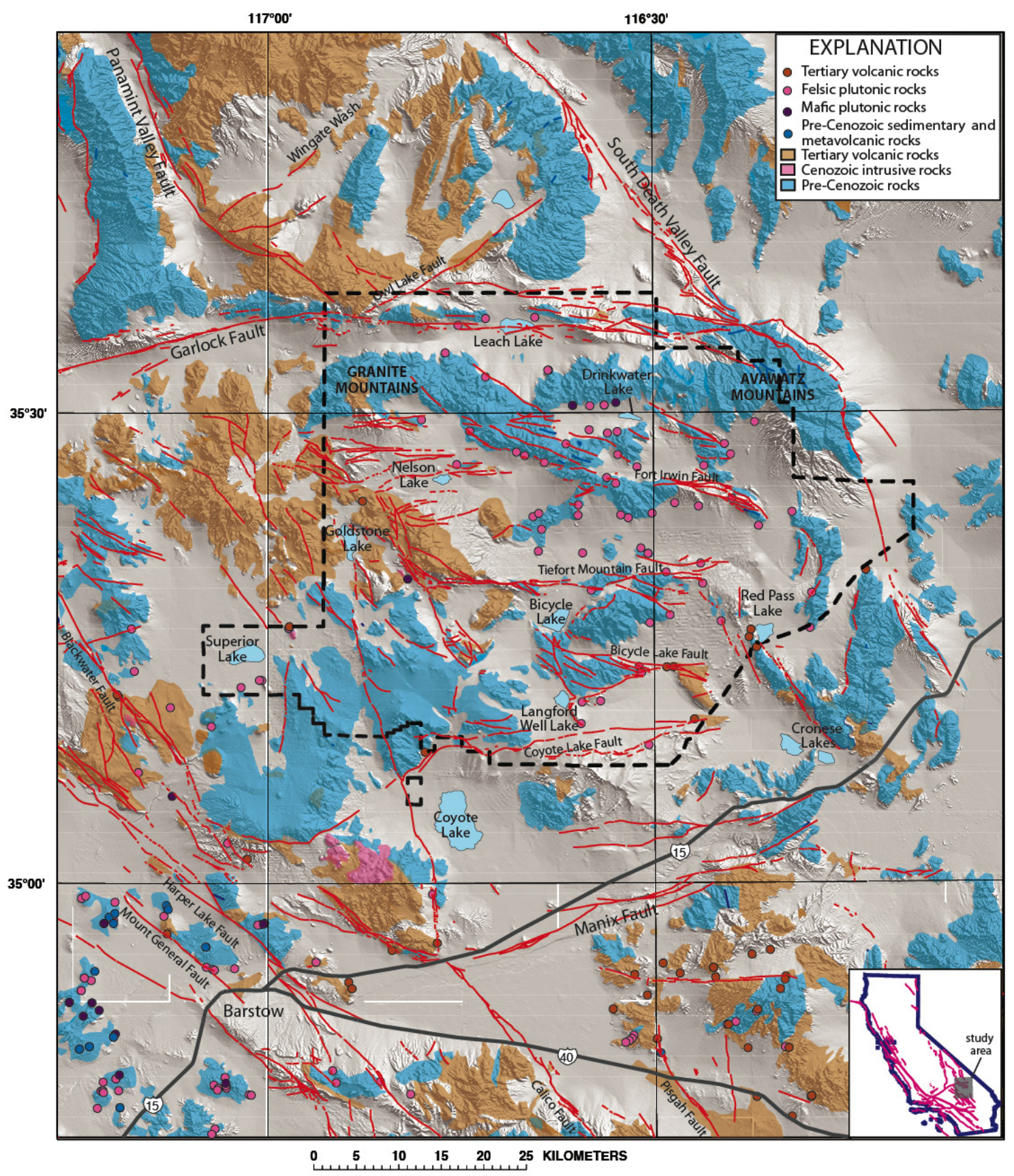

Figure 1. Simplified geologic map of Fort Irwin (outlined by dashed black line) over shaded-relief topography. Circles denote locations of magnetic-susceptibility measurements. Geology simplified from Jennings and others $(1962,1977) ;$ faults from Amoroso and Miller (2006), Jennings and Bryant (2010) and Miller and others (this volume, chap. B). 


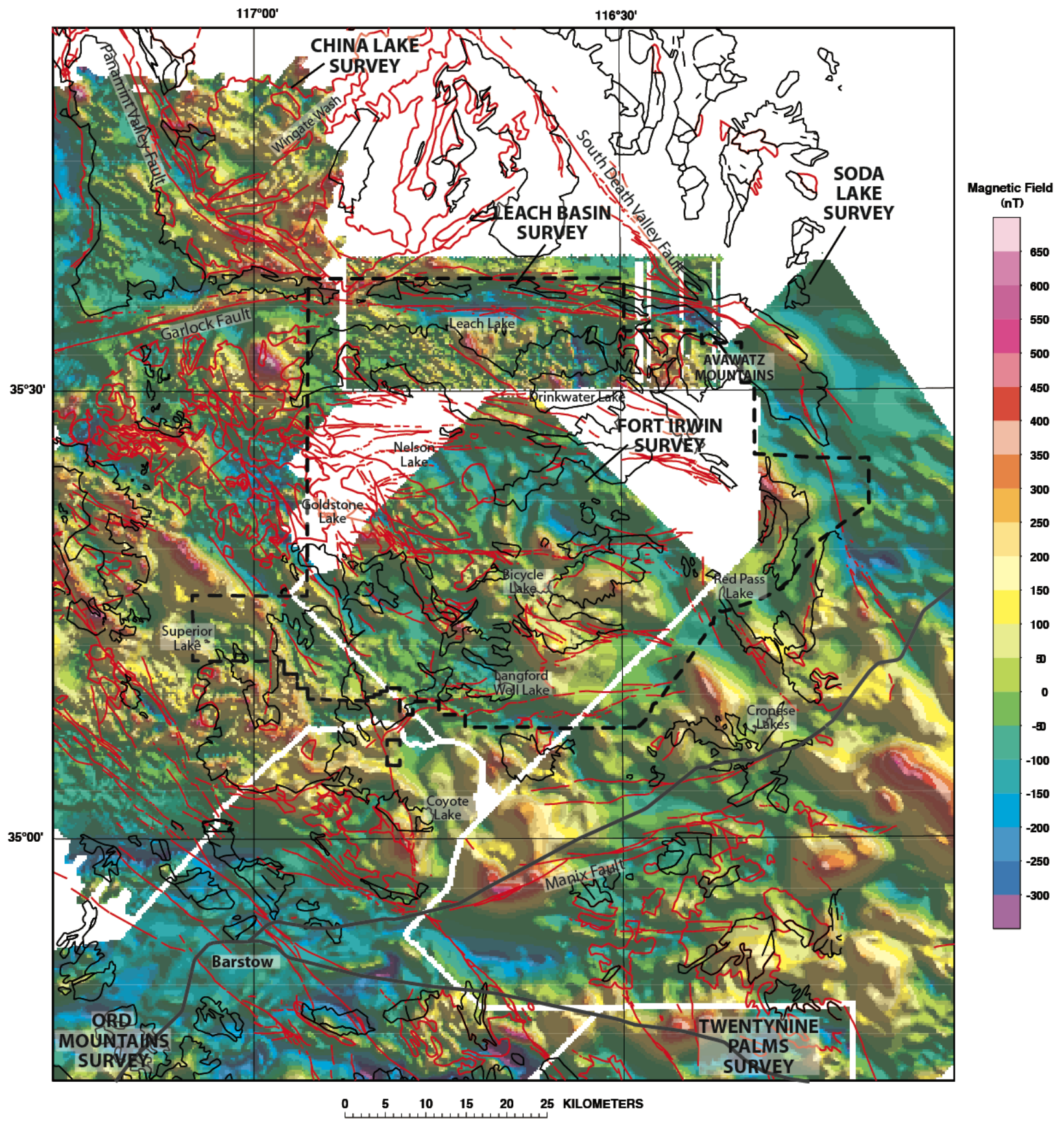

Figure 2. Mosaic map of detailed aeromagnetic data of the Fort Irwin study area (fig. 1). White lines denote edges of detailed surveys. 


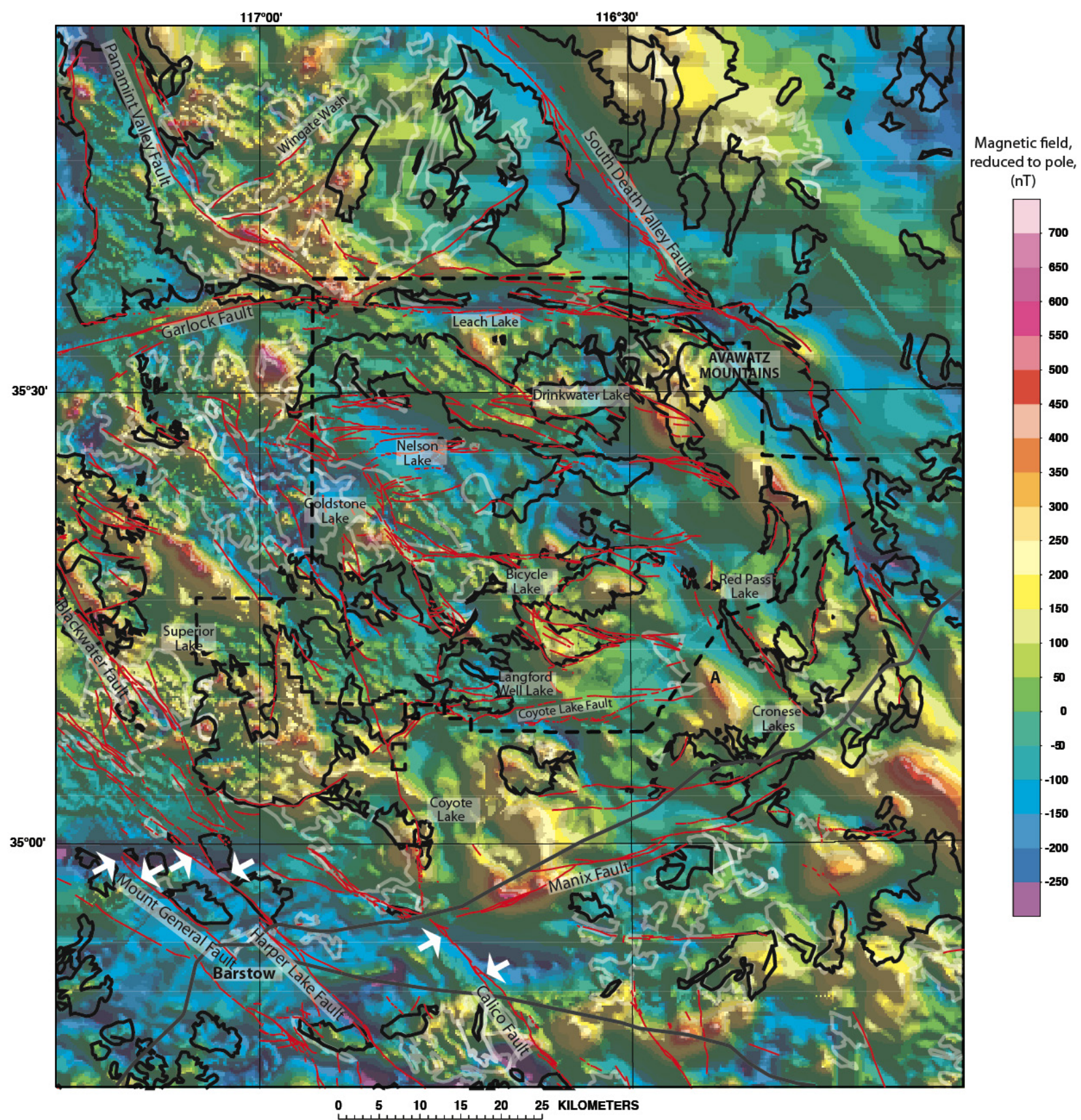

Figure 3. Merged aeromagnetic map of the Fort Irwin study area (fig. 1). Heavy black lines, outcrops of preCenozoic basement rocks; light gray outlines, outcrops of Tertiary volcanic rocks. White arrows point to offset magnetic anomalies along the Mount General, Harper Lake, and Calico Faults. 


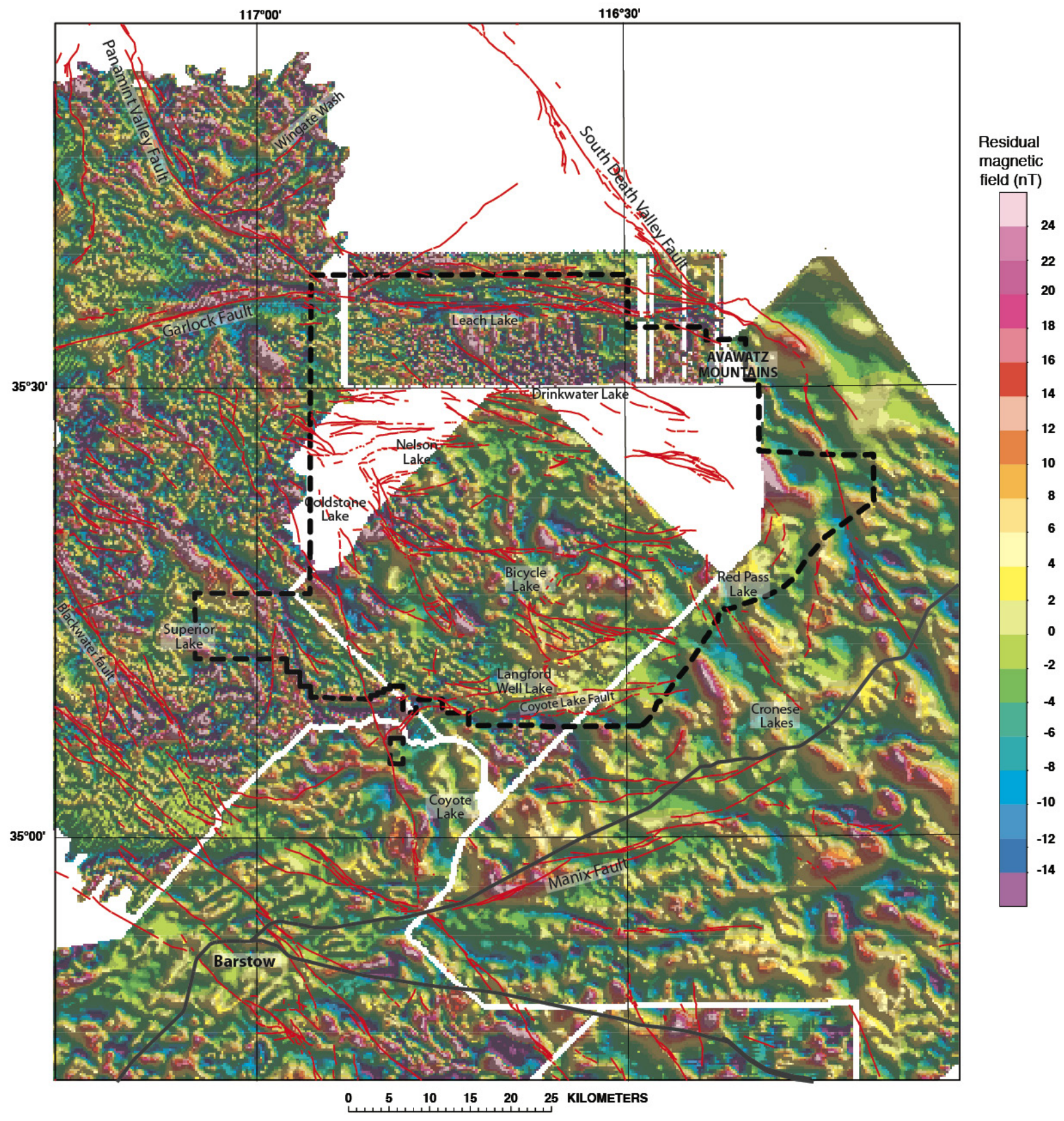

Figure 4. Filtered aeromagnetic map of the Fort Irwin study area (fig. 1) that enhances anomalies produced by shallow or exposed magnetic sources. 


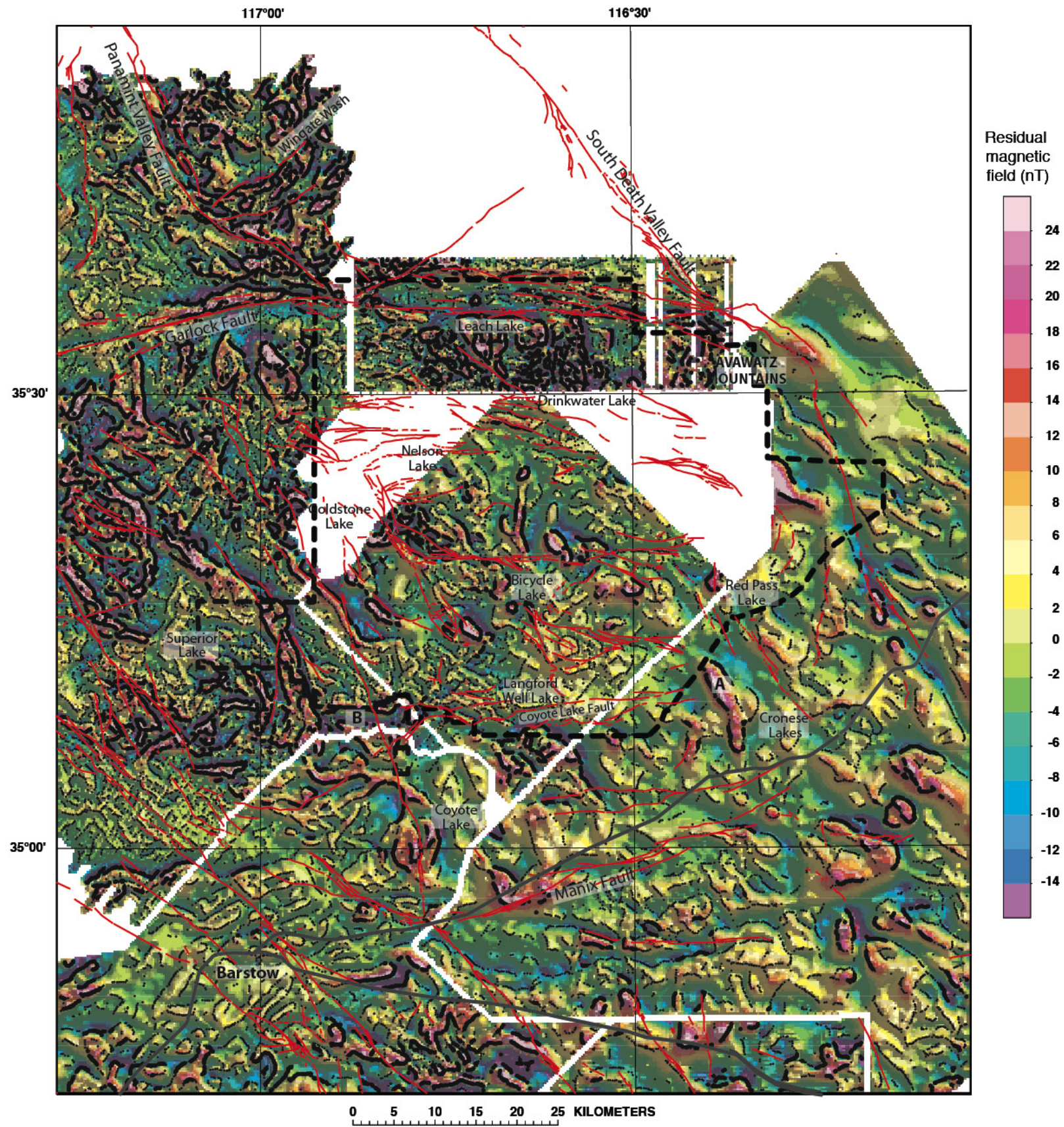

Figure 5. Filtered aeromagnetic map of the Fort Irwin study area (fig. 1) that enhances anomalies produced by shallow or exposed magnetic sources and shows magnetization boundaries (black dots). 


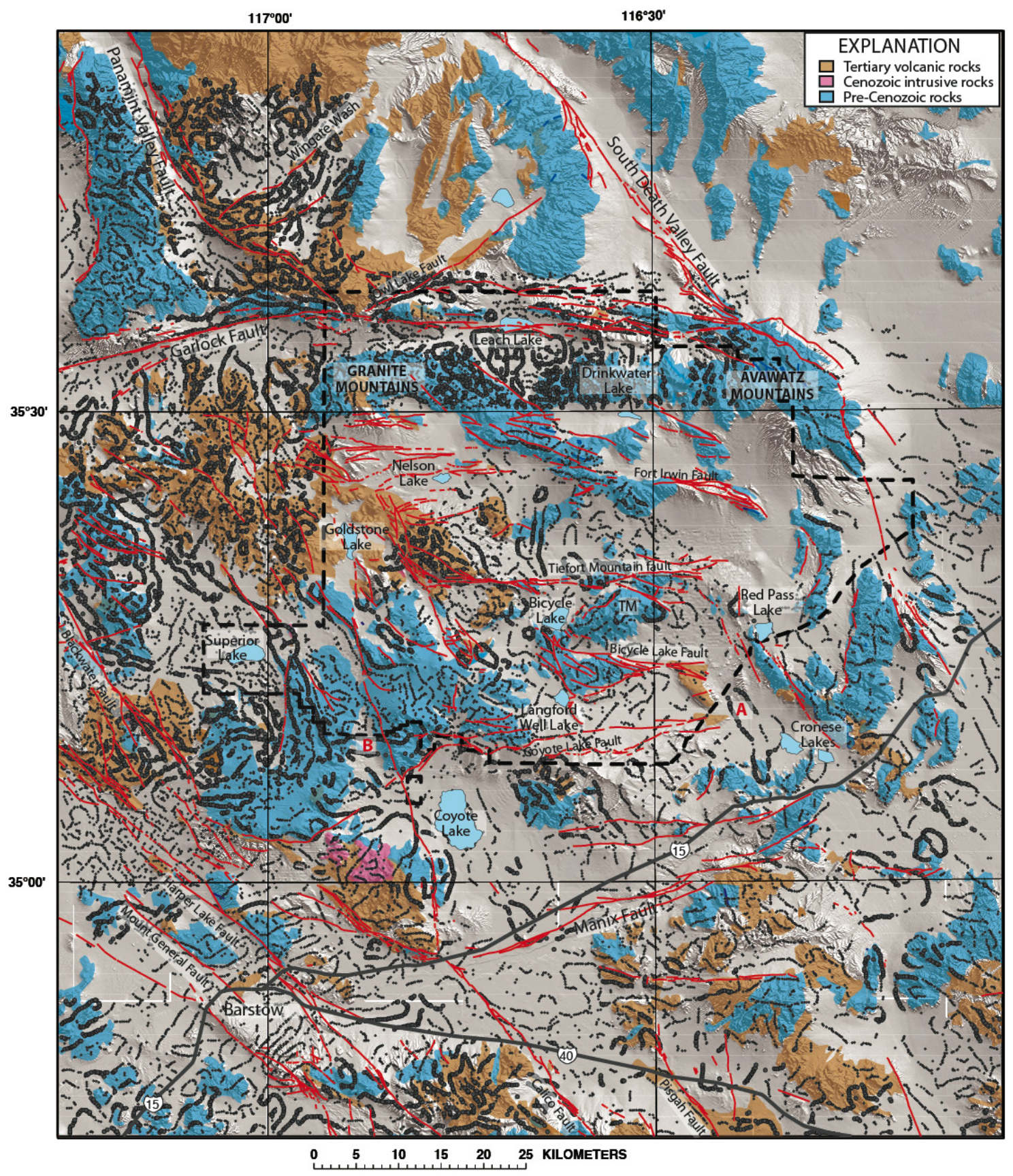

Figure 6. Magnetization boundaries superposed on simplified geologic map of the Fort Irwin study area (fig. 1). Features $A$ and $B$ are discussed in text. 


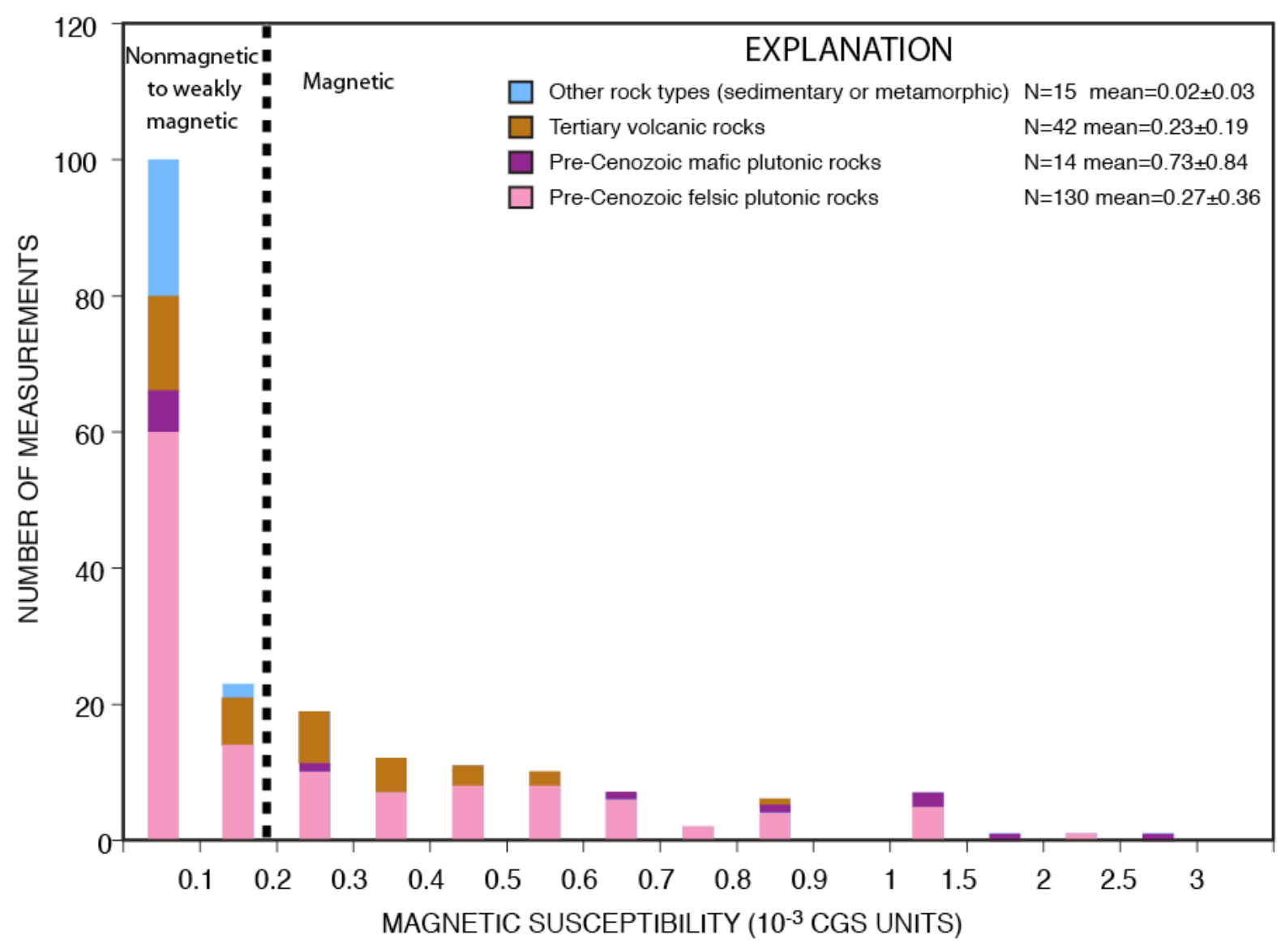

Figure 7. Bar chart of magnetic-susceptibility measurements from the Fort Irwin study area (fig. 1). 

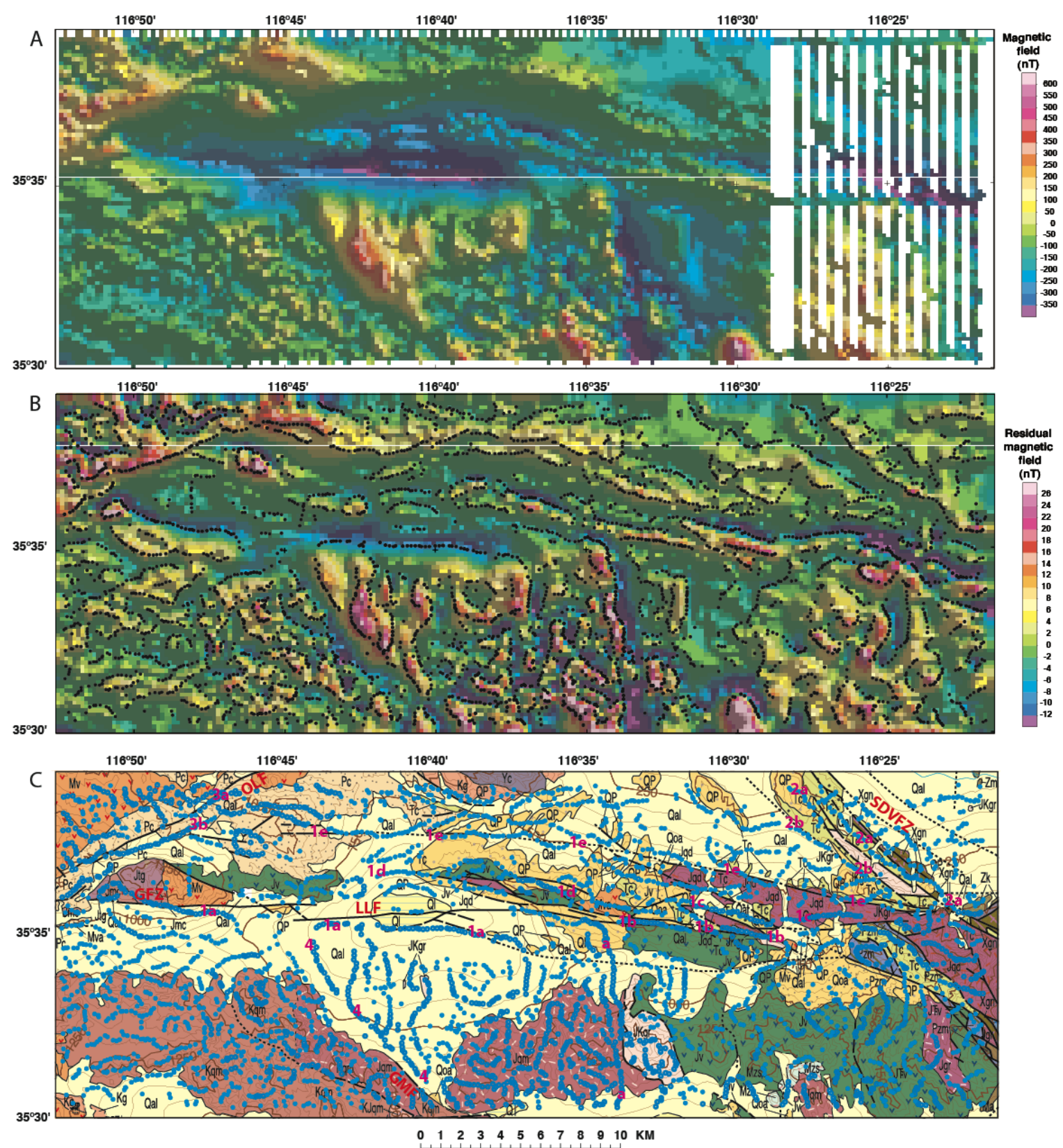

Figure 8. Aeromagnetic and derivative maps of Leach Basin high-resolution helicopter survey. A, Unfiltered aeromagnetic map. White areas in eastern quarter of map area are data gaps. B, Aeromagnetic map filtered to enhance anomalies arising from near-surface sources. Black dots, magnetization boundaries. C, Magnetization boundaries (blue circles and dots) superposed on geology from Walker and others (2002). GFZ, Garlock Fault Zone; GMF, Granite Mountains Fault; LLF, Leach Lake Fault; OLF, Owl Lake Fault; SDVFZ, Southern Death Valley Fault Zone. Magenta numbers refer to gradients associated with faults; a, north-south magnetic gradient that appears to be truncated by a strand of the Garlock Fault Zone. 
Table 1. Aeromagnetic-survey specifications.

[GPS, Global Positioning System]

\begin{tabular}{|c|c|c|c|c|c|c|c|c|}
\hline Name & Archive & Date flown & Flightline spacing & $\begin{array}{l}\text { Flightline } \\
\text { direction }\end{array}$ & $\begin{array}{l}\text { Flight height above } \\
\text { average terrain }(\mathrm{m})\end{array}$ & $\begin{array}{l}\text { Position } \\
\text { control }\end{array}$ & Sensor & Reference \\
\hline Twentynine Palms & CA26 & $9 / 1982$ & $1600 \mathrm{~m}$ & N-S & 300 & $\begin{array}{c}\text { Local } \\
\text { transponder? }\end{array}$ & $\begin{array}{l}\text { Proton } \\
\text { precession (?) }\end{array}$ & Roberts and Jachens (1999) \\
\hline China Lake & --- & 1995 & $800 \mathrm{~m}$ & NE-SW & 550 & GPS & Cesium vapor & Roberts and Jachens (1999) \\
\hline Fort Irwin & 4164 & 10/1994-1/1995 & $530 \mathrm{~m}$ & EW & 250 & GPS & Cesium & $\begin{array}{l}\text { U.S. Geological Survey and } \\
\text { National Geophysical Data } \\
\text { Center (2002) }\end{array}$ \\
\hline Soda Lake & --- & $6 / 2009$ & $800 \mathrm{~m}$ & EW & 300 & GPS & Cesium vapor & This report \\
\hline Ord Mountains & 4103 & $1957-58$ & $400 \mathrm{~m}$ & NE-SW & 150 & $\begin{array}{c}\text { Local } \\
\text { transponder? }\end{array}$ & $\begin{array}{l}\text { Proton } \\
\text { precession }\end{array}$ & U.S. Geological Survey (1985) \\
\hline Leach Basin & --- & $2010-11$ & $400,800 \mathrm{~m}$ & N-S & $\begin{array}{c}50 \\
\text { (helicopter) }\end{array}$ & GPS & Cesium vapor & This report \\
\hline
\end{tabular}

